\title{
Attacin - an insect immune protein - binds LPS and triggers the specific inhibition of bacterial outer-membrane protein synthesis
}

\author{
Anette Carlsson, ${ }^{1}$ Thomas Nyström, ${ }^{2}$ Hans de Cock $^{3}$ and Hans Bennich ${ }^{1}$
}

Author for correspondence: Anette Carlsson. Tel: +46 18 4714928. Fax: +4618557579.

e-mail: Anette.Carlsson@imim.uu.se

1 Department of Medical Biochemistry \&

Microbiology, Uppsala

University, Box 582,

S-75123 Uppsala, Sweden

2 Department of

Microbiology, Lund

University, Sölveg. 12,

S-22362 Lund, Sweden

3 Department of Molecular Cell Biology, Institute of Biomembranes, Utrecht University, Padualaan 8 , $3584 \mathrm{CH}$ Utrecht, The Netherlands

\begin{abstract}
Attacin is a $20 \mathrm{kDa}$ antibacterial protein, originally isolated from the immune haemolymph of Hyalophora cecropia. It has been demonstrated previously that attacin causes increased permeability of the outer membrane of Escherichia coli and inhibition of outer-membrane protein synthesis at the transcriptional level. This is accompanied by inhibition of growth. Here, LPS is shown to serve as the receptor for attacin and evidence is presented that attacin does not need to enter the cell to exert its activity. The increase in outer-membrane permeability precedes any increase in inner-membrane permeability by at least one generation time ( $\sim 55 \mathrm{~min})$, and the inhibiting effect of attacin on synthesis of outer-membrane proteins is detectable after only $10 \mathrm{~min}$. It is also shown that attacin causes induction of several stress proteins and increased synthesis of LPS within, respectively, 25 and $60 \mathrm{~min}$ of treatment. Based on the results presented, it is proposed that attacin has the unique ability to specifically interfere with synthesis of outer-membrane proteins without entering the inner membrane or cytoplasm.
\end{abstract}

Keywords: attacin, outer-membrane proteins, lipopolysaccharide, stress protein induction, Escherichia coli

\section{INTRODUCTION}

Attacin is a $20 \mathrm{kDa}$ immune protein produced in pupae of Hyalophora spp. (Lepidoptera) in response to bacterial infection (Hultmark et al., 1983). We have previously shown that there are two forms of attacin, one neutral (pI 7) and one basic (pI 9) (Engström et al., 1984a). The primary sequences of the two forms are $80 \%$ identical. The difference in $\mathrm{pI}$ is explained by a difference in aspartic acid content (Engström et al., 1984a; Kockum et al., 1984). Both forms contain three hydrophobic regions in the amino-terminal part (Engström et al., 1984a). Attacin-like proteins have been described in other insect species, such as Drosophila melanogaster (Flyg et al., 1986) and Sarcophaga peregrina (Ando et al., 1987). Attacin inhibits growth of Gram-negative bacteria and increases the permeability of the outer membrane (OM) (Engström et al., 1984b) a structure unique to Gram-negative cells serving as a permeability barrier to the passage of hydrophobic and large (> $800 \mathrm{Da}$ ) hydrophilic substances. The synthesis

Abbreviations: BPI, bactericidal/permeability-increasing protein; IM, inner membrane; OM, outer membrane; Omp, outer-membrane protein. of several OM proteins (Omps) is inhibited by attacin, and this occurs at least partly at the level of transcription (Carlsson et al., 1991).

In the present study we wanted to investigate further the mechanisms involved in this inhibition of Omp synthesis. Our main questions were: (a) is binding of attacin to the cell surface sufficient for the subsequent effects, or does it have to enter into the cell; (b) are there any other specific effects on protein synthesis; and (c) is LPS synthesis affected?

We show that LPS on the cell surface serves as the receptor for attacin and we suggest that the effects on Omp biosynthesis are achieved by an 'indirect mechanism', i.e. attacin does not need to enter the inner membrane (IM) or cytoplasm to turn off the synthesis of Omps.

\section{METHODS}

Preparation of attacin. Diapausing pupae of Hyalophora gloveri or Hyalophora cecropia were injected with $10^{5}$ live Enterobacter cloacae $\beta 12$ and the haemolymph was collected after $6-8 \mathrm{~d}$ as described by Hultmark et al. (1980) and stored at $-20^{\circ} \mathrm{C}$. Neutral and basic attacins were purified by salt 
Table 1. Bacterial strains

\begin{tabular}{|c|c|c|}
\hline Strain & Relevant characteristics & Reference or source* \\
\hline \multicolumn{3}{|l|}{ E. coli K-12 } \\
\hline MC4100 & LPS Ra & Casabadan (1976) \\
\hline D21 & $r f a$, LPS Ra & Boman et al. (1968) \\
\hline $\mathrm{D} 21 \mathrm{e} 7$ & $r f a$, LPS Rc & Eriksson-Grennberg et al. (1971) \\
\hline D21f1 & $r f a$, LPS Rd & Boman \& Monner (1975) \\
\hline D21f2 & $r f a$, LPS Re & Boman \& Monner (1975) \\
\hline CE1224 & $o m p R$, LPS Ra & Tommassen et al. (1983) \\
\hline CE1448 & CE1224 $\Delta(o m p T \operatorname{deg} P)$ & C. Jansen ${ }^{1}$ \\
\hline JM105 & pld $A^{+}$ & Yanisch-Peron et al. (1985) \\
\hline CE1349 & JM105 $\Delta p l d A$ & R. Brok ${ }^{1}$ \\
\hline KP1229 & $\mathrm{W} 3110 \Delta(a n a-\operatorname{ton} B-\operatorname{trp})$ & Ahmer et al. (1995) \\
\hline $\mathrm{MO} / \mathrm{pRZ} 540$ & $\operatorname{ton} B^{+}$ & Postle \& Reznikoff (1979) \\
\hline PC1989 & tolA & Phabagen Collection ${ }^{1}$ \\
\hline PC1990 & tolB & Phabagen Collection $^{1}$ \\
\hline AB1157 & $\mathrm{tol}^{+}$ & Tommassen et al. (1983) \\
\hline PND2000 & 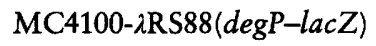 & Danese et al. (1995) \\
\hline AF633 & MC4100 $\lambda \Phi(u s p B-l a c Z)$ & A. Farewell \& T. Nyström ${ }^{2}$ \\
\hline AF634 & MC4100 $\lambda \Phi(u s p-l a c Z)$ & Farewell et al. (1996) \\
\hline TN 21512 & MC4100 $\lambda \Phi(b o l A-l a c Z)$ & A. Farewell \& T. Nyström ${ }^{2}$ \\
\hline \multicolumn{3}{|l|}{ P. mirabilis } \\
\hline EH193 & $r f a$, LPS Re & Kotelko (1986) \\
\hline
\end{tabular}

* 1, Utrecht University, The Netherlands; 2, Lund University, Sweden.

precipitation (ammonium sulphate) followed by ion exchange chromatography as previously described (Engström et al., 1984a).

Bacterial strains and growth conditions. The bacterial strains used are listed in Table 1 . Cells were grown at $37^{\circ} \mathrm{C}$ in $\mathrm{LB}$ medium or in M9 minimal medium [supplemented with $0.4 \%$ (w/v) glycerol and the amino acids required for the respective strains] as indicated. Growth experiments were performed in microtitre plates, with a culture volume of $200 \mu \mathrm{l}$. Attacin and/or other substances (e.g. $\mathrm{MgCl}_{2}$ ) to be tested were added to the growth medium and the medium was inoculated with 5 $\times 10^{6}$ cells in mid-exponential phase. The cultures were incubated at $37^{\circ} \mathrm{C}$ on a rotary shaker and growth was recorded every $30 \mathrm{~min}$ by a Multiskan spectrophotometer. Both forms of attacin were used in the experiments and yielded the same type of results, differing only in the degree of activity.

LPS derivatives in binding experiments. The origin of Escherichia coli LPS derivatives used for binding experiments was as follows: rough LPS of chemotype Rd, Sigma L6893; monophosphoryl lipid A, Sigma L6638; and diphosphoryl lipid A, Sigma L5399. Stock solutions of LPS were prepared at $1 \mathrm{mg} \mathrm{m}{ }^{-1}$ in distilled water, heated to $55^{\circ} \mathrm{C}$ for $20-30 \mathrm{~min}$, sonicated for $3 \mathrm{~min}$ and stored at $-20^{\circ} \mathrm{C}$. Prior to use the solutions were heated and sonicated. Stock solutions of lipid A $\left(0.5 \mathrm{mg} \mathrm{ml}^{-1}\right)$ were prepared in $0.025 \%(\mathrm{v} / \mathrm{v})$ triethanolamine in distilled water, sonicated for $3 \mathrm{~min}$ and stored at $4^{\circ} \mathrm{C}$. Prior to use the solutions were sonicated for $3 \mathrm{~min}$.

Assay of outer- and inner-membrane permeability. Cells were incubated in LB in the presence of IPTG (to induce $\beta$ galactosidase), with or without attacin. Samples were withdrawn after various times, centrifuged and the supernatants frozen. When all samples had been collected the supernatants were thawed and assays of $\beta$-lactamase (Lehrer et al., 1988) and $\beta$-galactosidase (Miller, 1972) were performed to indicate release of periplasmic and cytoplasmic proteins, respectively. The $\beta$-lactamase assay mixture contained $75 \mu$ l supernatant, $125 \mu \mathrm{lLB}$ and $15 \mu \mathrm{l}$ PADAC (pyridine-2-azo- $p$-dimethylaniline cephalosporin, $\left.0.2 \mathrm{mg} \mathrm{ml}^{-1}\right)$. The $\beta$-galactosidase assay mixture contained $75 \mu \mathrm{l}$ supernatant, $125 \mu \mathrm{l}$ Z-buffer (Miller, 1972) and $40 \mu \mathrm{l}$ ONPG $\left(4 \mathrm{mg} \mathrm{ml}^{-1}\right)$. The assay mixtures were incubated at $37^{\circ} \mathrm{C}$. The absorbance was determined at $560 \mathrm{~nm}$ for $\beta$-lactamase and $420 \mathrm{~nm}$ for $\beta$-galactosidase, and the optical density at $560 \mathrm{~nm}$ for cell cultures using a Multiskan spectrophotometer. The formula $A_{\text {assay }} \times$ (time $\times \mathrm{OD}_{\text {cell }} \times$ volume $)^{-1} \times 1000$ was used to calculate relative enzyme activities. $\left(A_{\text {assay }}=\right.$ absorbance in enzyme assay; $\mathrm{OD}_{\text {cell }}=$ optical density of cell culture at time of sample withdrawal; time = assay time).

Radioactive pulse-labelling of cellular proteins. Cells were grown in $\mathrm{M} 9$ minimal medium. Attacin was added at midexponential phase and samples were withdrawn at different times and transferred to tubes containing $30 \mu \mathrm{Ci} \mathrm{m}^{-1}\left(1.1 \times 10^{6}\right.$ $\mathrm{Bq} \mathrm{ml}{ }^{-1}$ ) L- ${ }^{35}$ S]methionine (> $37 \mathrm{TBq} \mathrm{mmol}^{-1}$; Amersham) and non-radioactive methionine to a final concentration of $65 \mathrm{nM}$ (to ensure linear incorporation during the labelling period). Labelling was stopped after $30 \mathrm{~s}$ by the addition of 1 vol. $20 \%(\mathrm{w} / \mathrm{v})$ trichloroacetic acid (TCA), or chased after $30 \mathrm{~s}$ with non-radioactive methionine (final concn $2 \mu \mathrm{M}$ ) for $3 \mathrm{~min}$ and then stopped by the addition of $1 \mathrm{vol} .20 \%$ TCA.

Radioactive labelling of LPS. Cells were grown in LB medium to mid-exponential phase. Attacin was added and samples were withdrawn at different times and transferred to tubes containing $20 \mu \mathrm{Ci} \mathrm{ml} \mathrm{m}^{-1}\left(7 \cdot 4 \times 10^{5} \mathrm{~Bq} \mathrm{ml} l^{-1}\right)$ of $\mathrm{D}-\left[\mathrm{U}-{ }^{14} \mathrm{C}\right]-$ galactose $\left(10.9 \mathrm{GBq} \mathrm{mmol}^{-1}\right)$ or $N$-acetyl-D-[1- $\left.{ }^{14} \mathrm{C}\right]$ glucosamine $\left(1.96 \mathrm{GBq} \mathrm{mmol}^{-1}\right)$ or $\left[2-{ }^{14} \mathrm{C}\right]$ acetate $(2.07 \mathrm{MBq}$ 
$\left.\mathrm{mmol}^{-1}\right)$. Labelling was continued for $60 \mathrm{~min}$ and then stopped by the addition of 1 vol. $20 \%$ TCA.

Gel electrophoresis, autoradiography and fluorography. SDS-PAGE was performed according to Laemmli (1970) with the modifications described by Randall \& Hardy (1977). Gels containing protein samples labelled with ${ }^{35} \mathrm{~S}$ were dried after staining with Coomassie brilliant blue, overlaid with Fuji film and exposed for $1-3 \mathrm{~d}$ at $-70^{\circ} \mathrm{C}$ for autoradiography.

Gels containing LPS samples labelled with ${ }^{14} \mathrm{C}$ were stained with silver (Tsai \& Frasch, 1982) and incubated for $30 \mathrm{~min}$ in $1 \mathrm{M}$ sodium salicylate (Chamberlain, 1979) before being dried and overlaid with Fuji film at $-70^{\circ} \mathrm{C}$ for fluorography.

Resolution of proteins by two-dimensional gel electrophoresis. Culture samples were processed to produce extracts for resolution by two-dimensional SDS-PAGE as described by O'Farrell (1975) with modifications (VanBogelen \& Neidhardt, 1990). Alphanumeric designations were assigned to protein spots after matching them to the reference twodimensional images of the gene protein database of $E$. coli (VanBogelen et al., 1990).

Coupling of attacin to agarose beads. Attacin was covalently coupled to agarose beads (Affi-Gel10, Bio-Rad) as described by LaPorte et al. (1977). Attacin (12 mg) in $0.1 \mathrm{M} \mathrm{NaHCO}_{3}$, $\mathrm{pH} 7.5$, was coupled to $0.5 \mathrm{ml}$ Affi-Gel. Underivatized agarose beads, i.e. beads treated as above but without attacin, were used as controls.

There are practical problems with this procedure: it requires a large amount of material and uncertainty of coupling efficiency makes it difficult to estimate the effective concentration of coupled attacin. To test LPS-binding ability we incubated agarose-coupled attacin, underivatised agarose and free attacin with solubilized LPS Rd for $30 \mathrm{~min}$ at $37^{\circ} \mathrm{C}$. The samples were analysed by SDS-PAGE followed by silver staining for LPS (Tsai \& Frasch, 1982). Since the results demonstrated that LPS was present in samples with agarosecoupled attacin as well as in those containing free attacin, whilst samples with underivatized agarose contained no detectable LPS, the protocol for coupling of attacin to agarose beads was judged to be satisfactory.

Assay of induction of stress proteins. Strains containing transcriptional fusions of various stress promoters with lacZ were incubated with or without attacin $(20 \mu \mathrm{M})$ in LB medium. Samples were withdrawn after various times and frozen. $\beta$ Galactosidase assays of the thawed culture samples were performed as described for the permeability assay, but using cell culture samples instead of supernatants. In addition to the strains listed in Table 1, we assayed strains from a commercial kit, the Pro-Tox (C) assay from Xenometrix, containing various stress-related gene promoters fused with $l a c Z$.

\section{RESULTS} The effect of attacin on $O M$ integrity is separate in
time from the effect on IM integrity

We previously concluded (Engström et al., 1984b) that the primary target for interaction with attacin is the $\mathrm{OM}$, and that this interaction causes the subsequent effect on protein synthesis. Possible damage to the IM appears to be a secondary effect, not essential for attacin action. These conclusions are reinforced here by the demonstration that when strain D21 was treated with attacin, leakage of $\beta$-lactamase from the periplasm into

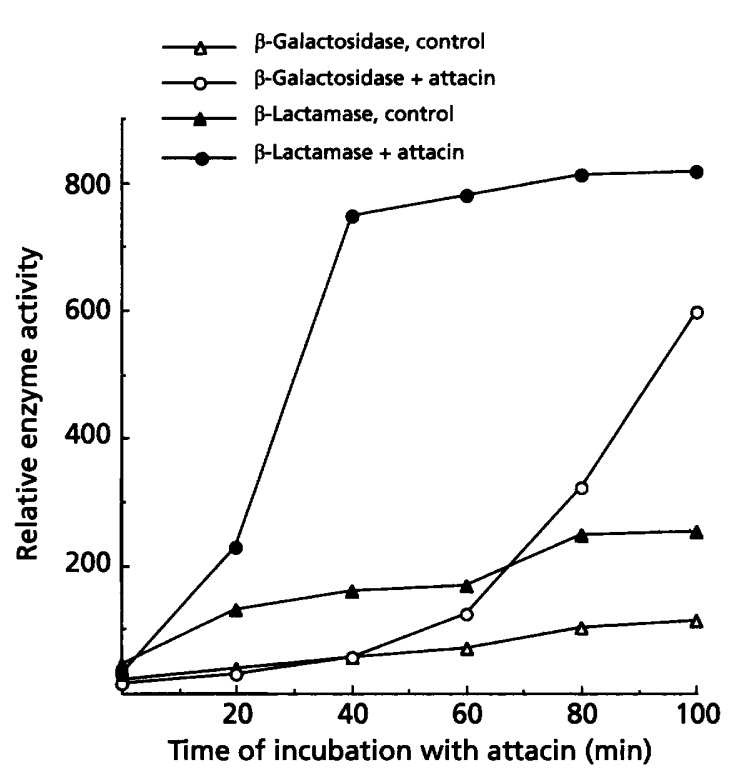

Fig. 1. $\beta$-Lactamase and $\beta$-galactosidase enzyme assays of supernatants from D21 cells incubated with $10 \mu \mathrm{M}$ attacin or without attacin. Values for relative enzyme activity were calculated as described in Methods.

the culture supernatant occurred early and increased rapidly (approx. $40 \%$ had leaked out after $40 \mathrm{~min}$ ). This damage to the OM barrier precedes the leakage of $\beta$ galactosidase from the cytoplasm by at least $40 \mathrm{~min}$ (Fig. 1). Less than $10 \%$ of the total content of $\beta$-galactosidase had leaked out by $2 \mathrm{~h}$. These results confirm our previous conclusion that the primary target of attacin is the OM.

\section{The LPS chemotype of the cell affects its sensitivity to attacin}

To determine if the LPS chemotype is important for the effect of attacin on the cell, we compared the growthinhibiting effect exerted by attacin on four isogenic $E$. coli $\mathrm{K}-12$ strains of different chemotypes, i.e. differing only in the length of the LPS core (Fig. 2). The deep rough, heptose-less strain D21f2 was the most sensitive and there was a step-wise decrease in sensitivity of the strains as the length of the LPS core increased. The effect on growth of strain D21 was very low at the concentration of attacin used $(10 \mu \mathrm{M})$, but nevertheless there was a significant effect on OM integrity (Fig. 1). These observations suggest that attacin interacts with the inner regions of the LPS moiety, since these parts are more exposed on the surface of cells having short LPS cores.

\section{Binding of attacin to LPS in solution inhibits its antibacterial activity}

To test if the activity of attacin is inhibited by free LPS, attacin was incubated with varying amounts of solubilized LPS of chemotype $\mathrm{Rd}$ at $37^{\circ} \mathrm{C}$ for $30 \mathrm{~min}$, 


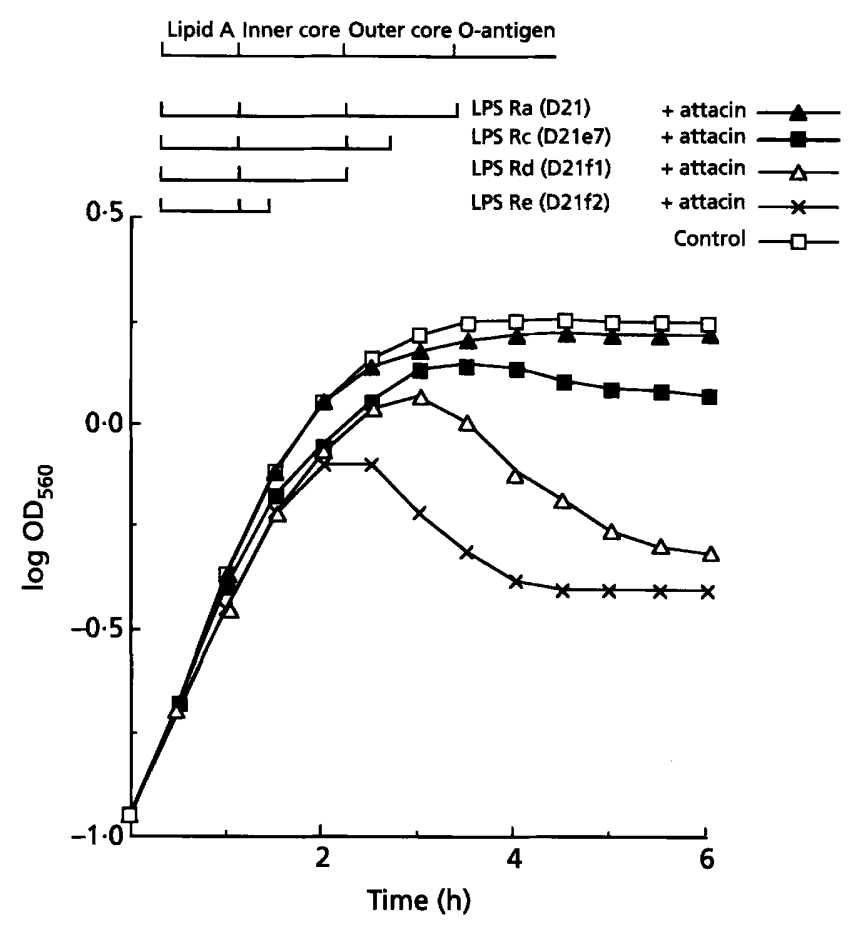

Fig. 2. Effect of attacin on growth of cells with different LPS chemotypes. Four $E$. coli strains were incubated in LB medium in the absence or presence of $10 \mu \mathrm{M}$ attacin. The control curve shown represents D21f2; results obtained with the other controls consisting of the other three strains were similar. A schematic representation of the polysaccharide chain length of the different LPS chemotypes is included.

whereafter the mixture was added to the cell culture (Fig. 3). Preincubation of attacin with a $5 \times$ molar excess of LPS totally abolished the growth-inhibiting effect of attacin. Using mono- and diphosphoryl lipid A instead of LPS also resulted in a decreased effect of attacin, but only partially. This indicates that an interaction of attacin with the inner core might be necessary for efficient binding.

\section{Polymyxin-resistant cells are sensitive to attacin}

Proteus mirabilis and other Proteus strains are inherently resistant to antibacterial cationic substances such as the insect immune peptide cecropin (Hultmark et al., 1980) and the lipopeptide polymyxin (Storm et al., 1977). For P. mirabilis (Sidorczyk et al., 1983), this resistance is suggested to be due to the high content of phosphate-linked 4-aminoarabinose in the LPS, which interferes with binding of cationic agents by making the LPS moiety less acidic (Vaara \& Vilianen, 1985). To investigate further the nature of binding of attacin to LPS, we tested the sensitivity of a deep rough, heptoseless $P$. mirabilis strain (EH193). We found that this strain was very sensitive to the neutral form of attacin, in fact as sensitive as would be expected from its Re chemotype, but was resistant to a 100-fold higher concentration of polymyxin than that which affected an

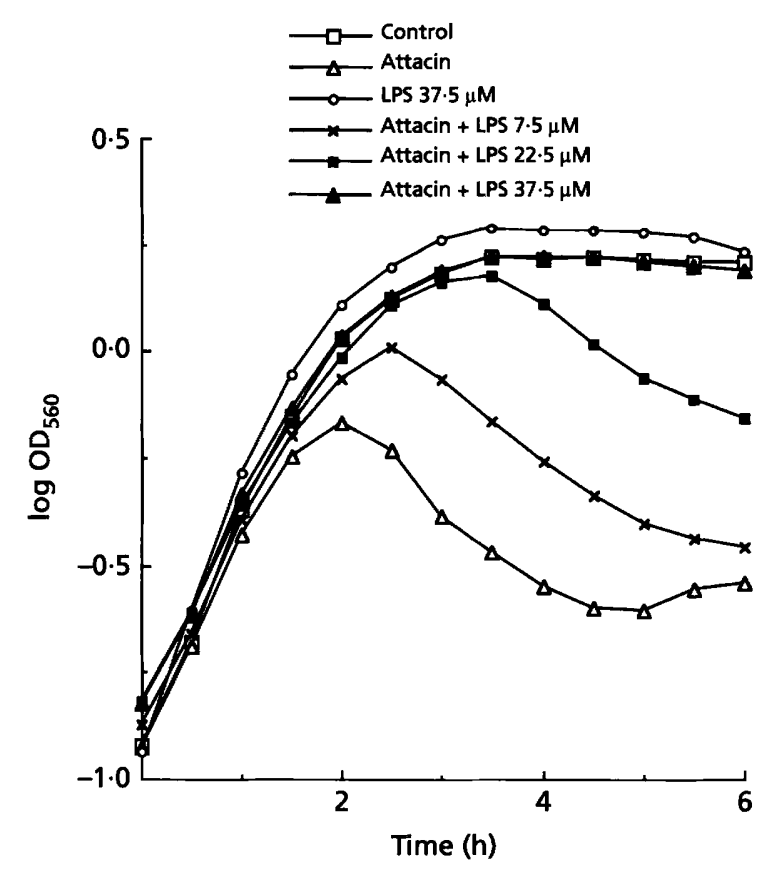

Fig. 3. Attacin interacts with purified LPS. Attacin (7.5 $\mu \mathrm{M})$ was incubated with varying concentrations of purified LPS Rd in LB medium for $30 \mathrm{~min}$ at $37^{\circ} \mathrm{C}$. These mixtures were then inoculated with exponential-phase D21f2 cells and growth was monitored at $560 \mathrm{~nm}$.

E. coli strain of the same chemotype. These results indicate that the mechanism for binding of attacin to LPS is different from that of polymyxin and cecropin.

Basic attacin is only half as active as the neutral form, but $P$. mirabilis is clearly also sensitive to the basic form. This is in contrast to the situation in E. coli, where basic attacin is approximately twice as active as the neutral form.

\section{$\mathbf{M g}^{2+}$ inhibits the bacteriostatic effect of attacin}

Divalent cations stabilize the OM. The addition of 40-50 $\mathrm{mM} \mathrm{Mg}^{2+}$ has been shown to abolish the antibacterial effects of polymyxin (Newton, 1953) and of the bactericidal/permeability-increasing protein (BPI) from mammalian neutrophils (Weiss et al., 1976). By adding $\mathrm{Mg}^{2+}$ at different concentrations together with attacin to growing cells, the effect on growth was inhibited in a dose-to-response fashion. Addition of $80 \mathrm{mM} \mathrm{Mg}{ }^{2+}$ completely abolished the effect of attacin. These results strengthen the suggestion that the negative charges in LPS are required for binding to attacin.

\section{Immobilized attacin can affect growing cells}

When added to cultures of strain D21f2, underivatized agarose beads had a minor effect on cell growth, whilst the agarose-coupled attacin caused a distinct effect, the growth curve having the shape that is characteristic for 


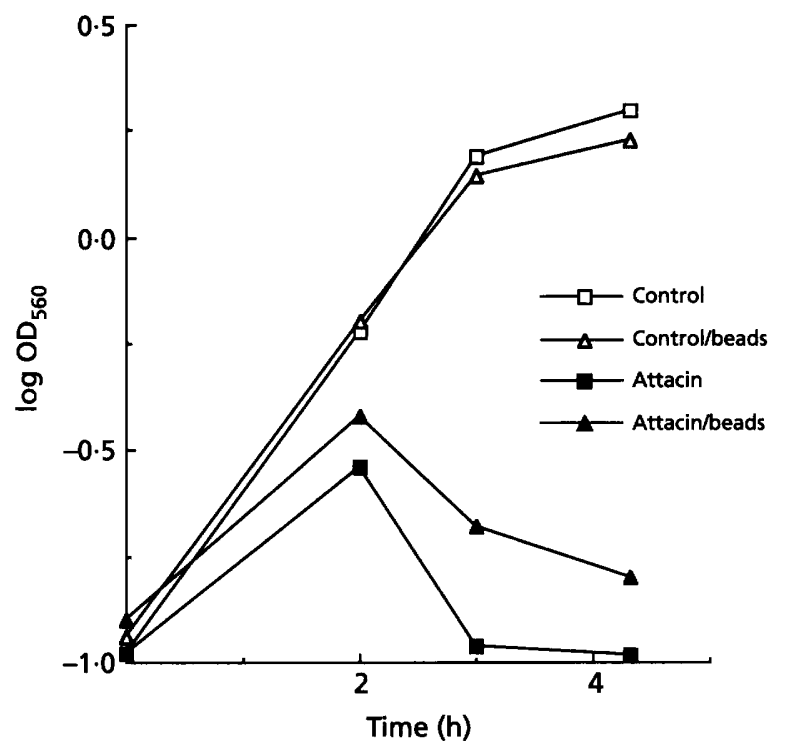

Fig. 4. Effect of immobilized attacin on growth of strain D21f2. Attacin was coupled to agarose beads and then added to growing cells to an approximate concentration of $15 \mu \mathrm{M}$ (assuming a $50 \%$ coupling efficiency). Beads without coupled protein were used as a control, as was uncoupled attacin $(10 \mu \mathrm{M})$.

the effect of unbound attacin on this strain (Fig. 4). Samples were taken after $3 \mathrm{~h}$ incubation, centrifuged and supernatants precipitated with TCA (10\% final concn) and analysed by SDS-PAGE to reveal a possible presence of cellular proteins as a sign of lysis/leakage. Large quantities of cellular proteins were present in the culture supernatants from cells incubated with either agarose-coupled or free attacin, whereas the supernatant from cells grown in the presence of underivatized beads did not contain more cellular protein than did the supernatant from untreated cells. These results indicate that attacin can affect growth and permeability without entering the cytoplasm.

\section{Attacin activity is not dependent on ton or tol}

To rule out two possible ways for attacin to enter the cell, we tested its effect on ton $B$, tolA and tolB mutant strains. TonB, an IM/periplasmic protein, is part of the Ton system, which is involved in uptake of large molecules, such as vitamin $B_{12}$, ferric siderophores and group B colicins (Braun, 1995). TolA and TolB are part of the Tol system, which is also involved in uptake of macromolecules, such as group A colicins (Webster, 1991). In addition, they are believed to be important for structural integrity of the cell. A tonB strain treated with attacin displayed the same effects on growth and on OM synthesis as a wild-type strain. The finding that growth of strains lacking either of the Tol proteins was more inhibited as compared to wild-type cells when incubated with attacin is likely to be due to changes in OM integrity. Thus, attacin does not depend on ton or tol for its activity.

\section{Attacin specifically inhibits the synthesis of Omps}

Our previous conclusion (Carlsson et al., 1991) that attacin inhibits the synthesis of $\mathrm{OmpF}, \mathrm{OmpC}$ and OmpA was confirmed here by two-dimensional SDSPAGE analysis of the protein content of attacin-treated cells (Fig. 5, Table 2). In addition, there was a decrease in two other Omps: FepA, a receptor for ferric enterochelin (Fiss et al., 1982) and CirA, a colicin I receptor and iron transporter (Konisky, 1979; Nikaido \& Rosenberg, 1990). The synthesis of several other, as yet identified proteins was also inhibited. All identified proteins that decreased in relative quantity were found to be Omps, which suggests a specific effect on their synthesis. No cytoplasmic precursors of Omps were detected on the two-dimensional gels, which indicates that attacin treatment does not lead to accumulation of export-defective proteins.

\section{Attacin induces synthesis of stress proteins}

We have previously observed induced synthesis of several unidentified proteins within $30 \mathrm{~min}$ of incubation with attacin and we suspected that they represent stress proteins. Use of two-dimensional SDS-PAGE analysis made it possible to identify two of the induced proteins as UspA and SspA (Fig. 5, Table 2). The UspA (universal stress protein $\mathrm{A}$ ) is induced by growth arrest (Nyström $\&$ Neidhardt, 1992). Expression of the SspA (stringent starvation protein A) is growth-regulated and induced by starvation for glucose, nitrogen, phosphate or amino acids (Williams et al., 1994).

We have also tested whether attacin induces $\beta$-galactosidase activity in $E$. coli strains containing transcriptional fusions of the promoters of bolA, $u s p A$ or $u s p B$ with lacZ. BolA is growth-rate- and $\sigma^{\mathrm{s}}$-dependent and required for the expression of the penicillin-binding protein PBP6, which plays a role in cell wall synthesis at the septum (Aldea et al., 1989). UspB is also regulated by $\sigma^{\mathrm{s}}$ and is induced by all starvation conditions so far tested (A. Farewell \& T. Nyström, unpublished results). All these gene fusions were induced as a result of the attacin treatment. In addition, we observed a clear induction of $\beta$-galactosidase activity in one of the ProTox (C) kit strains, containing an osm $\mathrm{Y}$ fusion. osm $\mathrm{Y}$ is a $\sigma^{\mathrm{s}}$-dependent gene encoding a protein that is induced during changes in medium osmolarity and also by growth rate (Lange \& Hengge-Aronis, 1991; Yim \& Villarejo, 1992). Thus, attacin promotes induced synthesis of proteins that are normally induced in response to slow growth, starvation and during transition to stationary phase.

\section{DegP is induced by attacin, but is not necessary for the effects on Omp synthesis}

If attacin disturbs the structure of the OM it might cause newly synthesized Omps to accumulate in the periplasm. This could result in an extracytoplasmic stress signal causing the induction of the periplasmic protease DegP (Lipinska et al., 1990; Mecsas et al., 1993; Danese et al., 

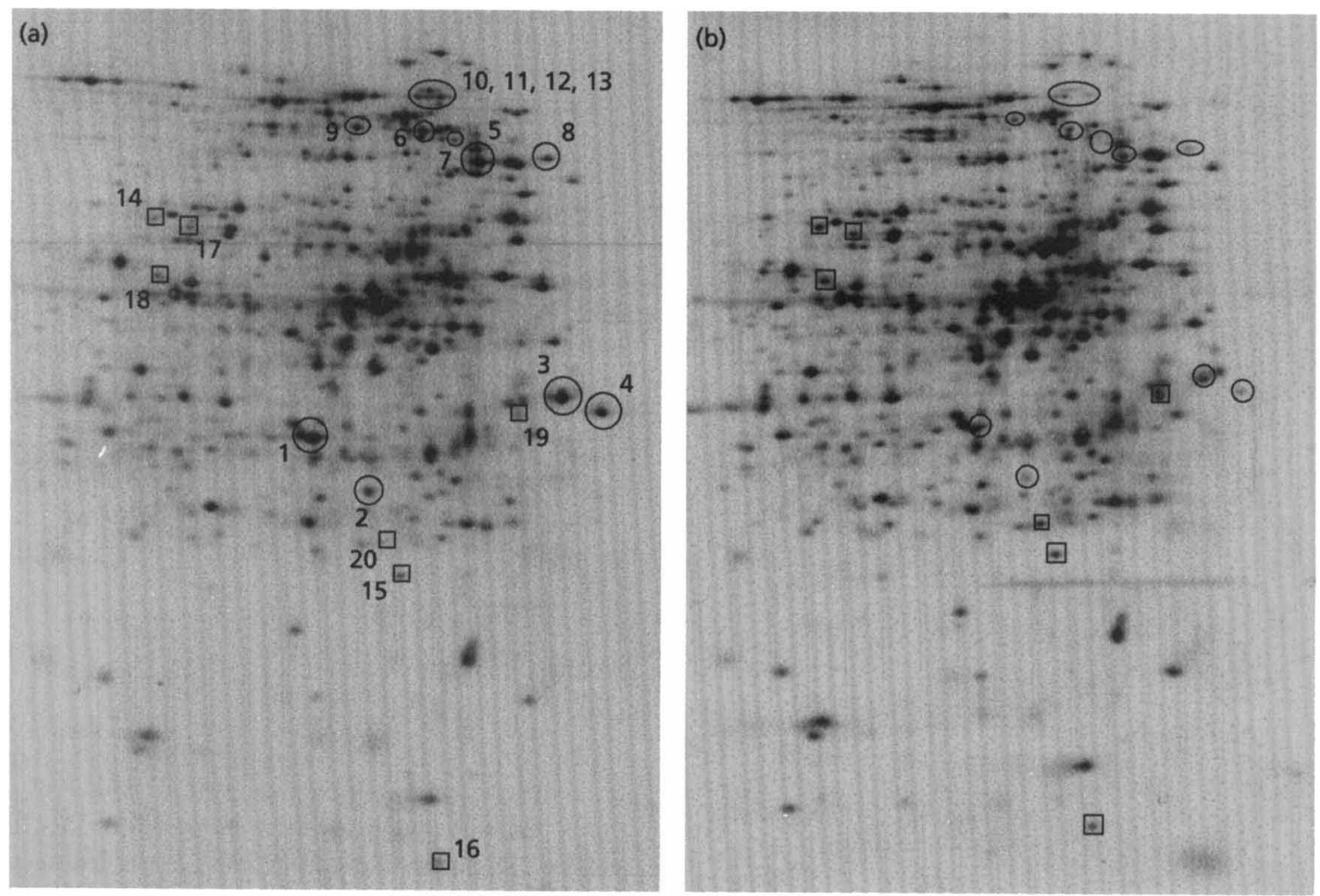

Fig. 5. Autoradiograms after two-dimensional PAGE of strain MC4100. Exponential-phase cells were incubated with $20 \mu \mathrm{M}$ attacin for $20 \mathrm{~min}$, then labelled with [ ${ }^{35} \mathrm{~S}$ ]methionine and processed for two-dimensional PAGE as described in Methods. The names of the proteins in the marked spots are listed in Table 2. (a) Untreated cells, (b) attacin-treated cells.

1995) Therefore, we treated a $\operatorname{deg} P-l a c Z$ fusion strain (PND2000) with attacin and assayed culture samples for $\beta$-galactosidase activity after various times of incubation. The results showed that there was indeed an induction of DegP, so that after $1 \mathrm{~h}$ the $\beta$-galactosidase activity was $1 \cdot 5$-fold higher and after $3 \mathrm{~h}$ it was $5 \cdot 3$-fold higher than the enzyme activity in untreated cells. This is late when compared to the time required to inhibit Omp synthesis $(10-30 \mathrm{~min})$. To test if DegP induction is a necessary step in the effect of attacin on protein synthesis, we used an E. coli mutant (CE1448) lacking DegP and also OmpT. OmpT is an OM protease (Baneyx \& Georgiou, 1990), possibly also involved in turnover of accumulated proteins. When CE1448 was incubated with attacin, it displayed an even stronger inhibition of growth as compared to the parent strain CE1224. The inhibitory effect on synthesis of OmpA, analysed by SDS-PAGE, was the same in both strains. Thus, though DegP is induced by attacin, it is not required for the effect on Omp synthesis. Neither is OmpT essential for this effect.

\section{Attacin affects the synthesis of LPS}

Porins depend on intact LPS for assembly in the OM. Cells that produce LPS with a defective core have a reduced synthesis of porins, due to feedback inhibition (Ried et al., 1990a). The same is true when lipid synthesis has been blocked with cerulenin, an antibiotic that inhibits fatty acid synthesis (Bocquet-Pages et al., 1981). This connection between Omps and LPS led us to investigate the effect of attacin on LPS synthesis. We labelled cells with $\left[{ }^{14} \mathrm{C}\right]$ galactose after incubation with attacin and analysed the LPS content by SDS-PAGE. The results show a clear increase in LPS synthesis after $1 \mathrm{~h}$ incubation with attacin (Fig. 6). The same results were obtained using $\left[{ }^{14} \mathrm{C}\right]$ acetate and $\mathrm{N}$-acetyl$\left[{ }^{14} \mathrm{C}\right]$ glucosamine. Thus, the effect of attacin on synthesis of Omps is likely to be a consequence of a perturbed membrane function/structure rather than a decrease in LPS synthesis.

\section{DISCUSSION}

The results presented in this paper suggest that LPS serves as a receptor for attacin. Accordingly, attacin that has been allowed to react with purified LPS does not inhibit growth of cells. Attacin shows the highest activity against deep rough, heptose-less cells, which lack long polysaccharide chains. This allows closer contact of attacin with the cell surface. Attacin is also inhibited by divalent cations that may compete for negatively charged phosphate groups on the inner parts of LPS that act as binding sites. Thus, electrostatic binding is likely to be important in the interaction of attacin with the bacterial cell. This would explain why basic attacin is more active than the neutral form on E. coli, and why 
Table 2. Proteins whose synthesis are affected by attacin

Numbers correspond to the marked spots in Fig. 5.

\begin{tabular}{|llc|}
\hline No. & Protein name & $\begin{array}{c}\text { Rate of synthesis } \\
\text { relative to } \\
\text { untreated control }{ }^{*}\end{array}$ \\
\hline 1 & OmpA & $0 \cdot 19$ \\
2 & OmpA & $0 \cdot 19$ \\
3 & OmpF & $0 \cdot 14$ \\
4 & OmpC & $0 \cdot 05$ \\
5 & CirA & $0 \cdot 08$ \\
6 & FepA & $0 \cdot 14$ \\
7 & Not identified & - \\
8 & Not identified & - \\
9 & Not identified & - \\
10 & Not identified & - \\
11 & Not identified & - \\
12 & Not identified & - \\
13 & Not identified & - \\
14 & DnaX & $4 \cdot 11$ \\
15 & SspA & $5 \cdot 40$ \\
16 & UspA & $1 \cdot 78$ \\
17 & Not identified & + \\
18 & Not identified & + \\
19 & Not identified & + \\
20 & Not identified & + \\
\hline
\end{tabular}

*Untreated control $=1$; + and - indicate increase and decrease in synthesis, respectively, rates not determined. SD $<10 \%$

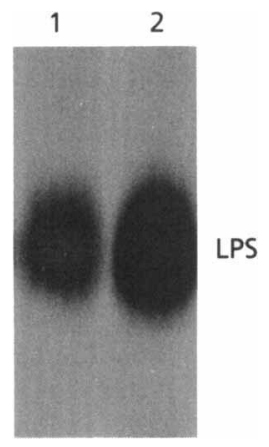

Fig. 6. Effect of attacin on the synthesis of LPS in strain MC4100. Autoradiogram after $18 \%$ SDS-PAGE of exponentialphase cells incubated with $20 \mu \mathrm{M}$ attacin for $1 \mathrm{~h}$ and then labelled with $\left[{ }^{14} \mathrm{C}\right]$ galactose for $30 \mathrm{~min}$ (in the continued presence of attacin) as described in Methods. Lanes: 1, untreated cells; 2 , attacin-treated cells. Only the relevant part of the gel is shown. The LPS nature of the bands was confirmed by silver staining of the gel containing a sample of purified LPS Rd (non-radioactive).

basic attacin is less active on Proteus, which has fewer negatively charged groups on its LPS.

In addition, the hydrophobic regions of attacin may interact with the acyl chains of lipid A and possibly also with phospholipids present in the OM. This theory is supported by the increased sensitivity of strains that have a more hydrophobic surface. The envA1 mutant strain D22 (Normark et al., 1969) displays an increased sensitivity to attacin compared to other strains with LPS of chemotype $\mathrm{Ra}$ (Hultmark et al., 1983). This strain has a $25-30 \%$ lower content of LPS, which is suggested to increase the exposure of the lipid bilayer (Grundström $e t$ al., 1980). The strain CE1224 used in this study also shows an increased sensitivity to attacin and to SDS (unpublished observation). CE1224 lacks the OmpF and OmpC porins due to an ompR::Tn10 mutation, and thus has a higher content of phospholipids in the OM. Deep rough strains have a lower amount of Omps but a higher content of phospholipids, which could add to the increased sensitivity due to the lack of polysaccharide chains on the surface (Nikaido \& Vaara, 1985).

Immobilized attacin is still able to inhibit cell growth. We cannot rule out the possibility that attacin, though tethered to the agarose beads, is able to partially translocate across the OM. However, we consider it unlikely that immobilized attacin would be able to interact with the transcription machinery in the cytoplasm. Our results suggest that an interaction of attacin with LPS receptor sites in the OM is sufficient to initiate the signalling for the subsequent shutdown of Omp synthesis.

The effect of attacin is restricted, only affecting synthesis of specific proteins. There are other reports of specific inhibition of Omp synthesis. The overexpression of an Omp or an aberrant Omp structure will inhibit the synthesis of other major Omps (Click \& Schnaitman, 1989; Catron \& Schnaitman, 1987; Ried et al., 1990b). Also, expression of an Enterobacter Omp in E. coli causes reduction of synthesis of endogenous Omps (Stoorvogel et al., 1991). Irrespective of the level on which these feedback mechanisms operate (transcription, mRNA stability, translation), these results indicate the existence of a common regulatory mechanism for (a subset of) Omps. However, what makes attacin unique is that it causes a disturbance from the outside of the cell, whereas overexpressed or mutated Omps provide a disturbance coming from the inside.

How is the effect on transcription accomplished? There are examples of systems for signalling from the outside or surface of the cell to the interior, such as the Pup system in Pseudomonas putida (Koster et al., 1994) and the ferric citrate system in E. coli (Härle et al., 1995). TonB is involved in both of these signalling processes. Here we show that TonB is not involved in the effect of attacin on Omp synthesis. However, there might be other similar systems, involving hitherto unidentified signal transducers.

We have also ruled out the involvement of DegP in the effect of attacin on protein synthesis. The observed induction of DegP might be required to degrade Omps that are prevented from assembling in the OM, to relieve the extracytoplasmic stress signal(s) induced by attacin. This proposal is supported by the findings that a $\operatorname{deg} P$ 
strain is even more sensitive to attacin as it has less ability to reduce the effects of stress. Thus, the induction of DegP is concluded to represent a secondary consequence of the binding of attacin to the OM.

A comparison of attacin with polymyxin and BPI is interesting. Although all three substances bind to LPS/lipid A and will affect the integrity of the OM, there are obvious and important differences. Qi et al. (1995) have performed two-dimensional PAGE analyses on Salmonella typhimurium cells treated with BPI or polymyxin. The majority of the affected proteins are involved in key metabolic processes. BPI and polymyxin cause different cellular responses, which in turn differ from the response caused by attacin on E. coli.

The small polymyxin molecule $(1.2 \mathrm{kDa})$ is assumed to enter the cell by self-promoted uptake (Hancock \& Bell, 1988 ) and interact with the IM (Storm et al., 1977), but as shown by LaPorte et al. (1977), it can also affect IM functions when it is immobilized by coupling to agarose beads. The mechanism for the action of BPI has not been completely elucidated. As is the case with attacin, deep rough mutants are more sensitive to BPI than cells carrying LPS molecules with longer polysaccharide chains (Weiss et al., 1980). BPI is believed to affect the IM and it has been speculated that it may enter the cell in a colicin-like fashion, i.e. it unfolds and enters through the OM to interact directly with the IM (Qi et al., 1995). BPI has been assumed to be inactive on P. mirabilis, but Capodici et al. (1994) have shown that a deep rough mutant of $P$. mirabilis is in fact sensitive to BPI. Though similar results are obtained with attacin, two-dimensional analyses demonstrate that there are differences in the range of proteins whose synthesis is affected by the respective proteins.

\section{Conclusion}

Our hypothesis for the interaction of attacin with Gramnegative bacteria is as follows. LPS in the bacterial envelope serves as a receptor for attacin. Electrostatic binding of positive charges on the attacin molecule to negative charges on the inner core- and lipid-A-regions of LPS, followed by hydrophobic interactions with lipid $A$ (and possibly also phospholipids in the OM), result in partial integration of attacin into the OM. This external blockage of presumably physiological reaction sites for Omps elicits signal(s) that mimic those occurring in vivo in conjunction with $\mathrm{OM}$ assembly to regulate $\mathrm{Omp}$ synthesis. Accordingly, the presence in the periplasm of any Omps being prevented from integrating into the $O M$ is likely to be an essential part of the signalling events that lead to inhibition of Omp synthesis at the transcriptional level. The observed increase in LPS synthesis is interpreted as an attempt by the cell to restore the integrity of the OM. In contrast to the early and specific effects of attacin on Omp expression, the later events, such as induced synthesis of stress proteins, represent secondary effects related to a perturbed membrane, decreased growth rate and/or starvation of the cell.

\section{ACKNOWLEDGEMENTS}

We thank Ronald Brok, Penelope Higgs, Carmen Jansen and Martti Vaara for providing bacterial strains. We are grateful to Dr Linda Randall, Washington State University, Pullman, USA and Dr Elizabeth Willott, University of Arizona, Tucson, USA for constructive comments on the manuscript.

This work was supported by grants from The Swedish Natural Science Research Council (grant no B-02964).

\section{REFERENCES}

Ahmer, B. M. M., Thomas, M. G., Larsen, R. A. \& Postle, K. (1995). Characterization of the exbBD operon of Escherichia coli and the role of ExbB and ExbD in TonB function and stability. $J$ Bacteriol 177, 4742-4747.

Aldea, M., Garrido, T., Hernández-Chico, C., Vicente, M. \& Kushner, S. R. (1989). Induction of a growth-phase-dependent promoter triggers transcription of bolA, an Escherichia coli morphogene. EMBO J 8, 3923-3931.

Ando, K., Okada, M. \& Natori, S. (1987). Purification of sarcotoxin II, antibacterial proteins of Sarcophaga peregrina (flesh fly) larvae. Biochemistry 26, 226-230.

Baneyx, F. \& Georgiou, G. (1990). In vivo degradation of secreted fusion proteins by the Escherichia coli outer membrane protease Omp T. J Bacteriol 172, 491-494.

Bocquet-Pages, C., Lazdunski, C. \& Lazdunski, A. (1981). Lipidsynthesis dependent biosynthesis (or assembly) of major outer membrane proteins of Escherichia coli. Eur J Biochem 118, 105-111.

Boman, H. G. \& Monner, D. A. (1975). Characterization of lipopolysaccharides from Escherichia coli $\mathrm{K}-12$ mutants. J Bacteriol 121, 455-464.

Boman, H. G., Eriksson-Grennberg, K. G., Normark, S. \& Matsson, E. (1968). Resistance of Escherichia coli to penicillins. IV. Genetic study of mutants resistant to $\mathrm{D}, \mathrm{L}$-ampicillin concentrations of $100 \mu \mathrm{g} / \mathrm{ml}$. Genet Res 12, 169-185.

Braun, V. (1995). Energy-coupled transport and signal transduction through the Gram-negative outer membrane via TonBExbB-ExbD-dependent receptor proteins. FEMS Microbiol Rev 16, 295-307.

Capodici, C., Chen, S., Sidorczyk, Z., Elsbach, P. \& Weiss, J. (1994). Effect of lipopolysaccharide (LPS) chain length on interactions of bactericidal/ permeability-increasing protein and its bioactive 23kilodalton $\mathrm{NH}_{2}$-terminal fragment with isolated LPS and intact Proteus mirabilis and Escherichia coli. Infect Immun 62, 259-265.

Carlsson, A., Engström, P., Palva, E. T. \& Bennich, H. (1991). Attacin, an antibacterial protein from Hyalophora cecropia, inhibits synthesis of outer membrane proteins in Escherichia coli by interfering with omp gene transcription. Infect Immun 59, 3040-3045.

Casabadan, M. J. (1976). Transposition and fusion of the lac genes to selected promoters in Escherichia coli using bacteriophage Lambda and Mu. J Mol Biol 104, 541-555.

Catron, K. M. \& Schnaitman, C. A. (1987). Export of protein in Escherichia coli: a novel mutation in ompC affects expression of other major outer membrane proteins. J Bacteriol 169, 4327-4334.

Chamberlain, J. P. (1979). Fluorographic detection of radioactivity in polyacrylamide gels with the water-soluble fluor, sodium salicylate. Anal Biochem 98, 132-135.

Click, E. M. \& Schnaitman, C. A. (1989). Export-defective LamB protein is a target for translational control caused by OmpC porin overexpression. J Bacteriol 171, 616-619. 
Danese, P. N., Snyder, W. B., Cosma, C. L., Davis, L. J. B. \& Silhavy, T. J. (1995). The Cpx two-component signal transduction pathway of Escherichia coli regulates transcription of the gene specifying the stress-inducible periplasmic protease, DegP. Genes Dev 9, 387-398.

Engström, Å., Engström, P., Tao, Z.-j., Carlsson, A. \& Bennich, H. (1984a). Insect immunity. The primary structure of the antibacterial protein attacin $\mathrm{F}$ and its relation to two native attacins from Hyalophora cecropia. EMBO J 3, 2065-2070.

Engström, P., Carlsson, A., Engström, Å., Tao, Z.-j. \& Bennich, H. (1984b). The antibacterial effect of attacins from the silk moth Hyalophora cecropia is directed against the outer membrane of Escherichia coli. EMBO J 3, 3347-3351.

Eriksson-Grennberg, K. G., Nordström, K. \& Englund, P. (1971). Resistance of Escherichia coli to penicillins. IX. Genetics and physiology of class II ampicillin-resistant mutants that are galactose negative or sensitive to bacteriophage $\mathrm{C} 21$, or both. J Bacteriol 108, 1210-1223.

Farewell, A., Diez, A. A., DiRusso, C. C. \& Nyström, T. (1996). Role of the Escherichia coli FadR regulator in stasis survival and growth phase-dependent expression of the uspA, fad, and fab genes. J Bacteriol 178, 6443-6450.

Fiss, E. H., Stanley-Samuelson, P. \& Neilands, J. B. (1982). Properties and proteolysis of ferric enterobactin outer membrane receptor in Escherichia coli K12. Biochemistry 21, 4517-4522.

Flyg, C., Dalhammar, G., Rasmuson, B. \& Boman, H. G. (1986). Insect immunity: inducible antibacterial activity in Drosophila melanogaster. Insect Biochem 17, 153-160.

Grundström, T., Normark, S. \& Magnusson, K.-E. (1980). Overproduction of outer membrane protein suppresses envA-induced hyperpermeability. J Bacteriol 144, 884-890.

Hancock, R. E. W. \& Bell, A. (1988). Antibiotic uptake into gramnegative bacteria. Eur J Clin Microbiol Infect Dis 7, 713-720.

Härle, C., Kim, I., Angerer, A. \& Braun, V. (1995). Signal transfer through three compartments: transcription initiation of the Escherichia coli ferric citrate transport system from the cell surface. EMBO J 14, 1430-1438.

Hultmark, D., Steiner, H., Rasmuson, T. \& Boman, H. G. (1980). Insect immunity. Purification and properties of three inducible bactericidal proteins from hemolymph of immunized pupae of Hyalophora cecropia. Eur J Biochem 106, 7-16.

Hultmark, D., Engström, Å., Andersson, K., Steiner, H., Bennich, H. \& Boman, H. (1983). Insect immunity. Attacins, a family of antibacterial proteins from Hyalophora cecropia. EMBO J 2, 571-576.

Kockum, K., Faye, I., von Hofsten, P., Lee, J.-Y., Xanthopoulus, K. G. \& Boman, H. G. (1984). Insect immunity. Isolation and sequence of two cDNA clones corresponding to acidic and basic attacins from Hyalophora cecropia. EMBO J 3, 2071-2075.

Konisky, J. (1979). Specific transport systems and receptors for colicins and phages. In Bacterial Outer Membranes: Biogenesis and Function, pp. 319-359. Edited by M. Inouye. New York: Wiley.

Koster, M., van Klompenburg, W., Bitter, W., Leong, J. \& Weisbeek, P. (1994). Role for the outer membrane ferric siderophore receptor PupB in signal transduction across the bacterial cell envelope. EMBO J 13, 2805-2813.

Kotelko, K. (1986). Proteus mirabilis: taxonomic position, peculiarities of growth, components of the cell envelope. Curr Top Microbiol Immunol 129, 181-215.

Laemmli, U. K. (1970). Cleavage of structural proteins during the assembly of the head of bacteriophage T4. Nature 227, 680-685.
Lange, R. \& Hengge-Aronis, R. (1991). Identification of a central regulator of stationary-phase gene expression in Escherichia coli. Mol Microbiol 5, 49-59.

LaPorte, D. C., Rosenthal, K. S. \& Storm, D. R. (1977). Inhibition of Escherichia coli growth and respiration by polymyxin $\mathrm{B}$ covalently attached to agarose beads. Biochemistry 16, 1642-1648.

Lehrer, R. I., Barton, A. \& Ganz, T. (1988). Concurrent assessment of inner and outer membrane permeabilization and bacteriolysis in $E$. coli by multiple-wavelength spectrophotometry. J Immunol Methods 108, 153-158.

Lipinska, B., Zylicz, M. \& Georgopoulus, C. (1990). The HtrA (DegP) protein, essential for Escherichia coli survival at high temperatures, is an endopeptidase. J Bacteriol 172, 1791-1797.

Mecsas, J., Rouviere, P. E., Erickson, J. W., Donohue, T. J. \& Gross, C. A. (1993). The activity of $\sigma^{\mathrm{E}}$, an Escherichia coli heat-inducible$\sigma$-factor, is modulated by expression of outer membrane proteins. Genes Dev 7, 2618-2628.

Miller, J. H. (1972). Experiments in Molecular Genetics. Cold Spring Harbor, NY: Cold Spring Harbor Laboratory.

Newton, B. A. (1953). Reversal of the antibacterial activity of polymyxin by divalent cations. Nature 172, 160-161.

Nikaido, H. \& Rosenberg, E. Y. (1990). Cir and Fiu proteins in the outer membrane of Escherichia coli catalyze transport of monomeric catechols: study with $\beta$-lactam antibiotics containing catechol and analogous groups. J Bacteriol 172, 1361-1367.

Nikaido, H. \& Vaara, M. (1985). Molecular basis of bacterial outer membrane permeability. Microbiol Rev 49, 1-32.

Normark, S., Boman, H. G. \& Matsson, E. (1969). Mutant of Escherichia coli with anomalous cell division and ability to decrease episomally and chromosomally mediated resistance to ampicillin and several other antibiotics. J Bacteriol 97, 1334-1342.

Nyström, T. \& Neidhardt, F. C. (1992). Cloning, mapping and nucleotide sequencing of a gene encoding a universal stress protein in Escherichia coli. Mol Microbiol 6, 3187-3198.

O'Farrell, P. H. (1975). High resolution two-dimensional electrophoresis of proteins. J Biol Chem 250, 4007-4021.

Postle, K. \& Reznikoff, W.S. (1979). Identification of the Escherichia coli tonB gene product in minicells containing tonB hybrid plasmids. J Mol Biol 131, 619-636.

Qi, S.-Y., Li, Y., Szyroki, A., Giles, I. G., Moir, A. \& O'Connor, C. D. (1995). Salmonella typhimurium responses to a bactericidal protein from human neutrophils. Mol Microbiol 17, 523-531.

Randall, L. L. \& Hardy, S.J. S. (1977). Synthesis of exported proteins by membrane-bound polysomes from Escherichia coli. Eur J Biochem 75, 43-53.

Ried, G., Hindennach, I. \& Henning, U. (1990a). Role of lipopolysaccharide in assembly of Escherichia coli outer membrane proteins OmpA, OmpC, and OmpF. J Bacteriol 172, 6048-6053.

Ried, G., Macintyre, S., Mutschler, B. \& Henning, U. (1990b). Export of altered forms of an Escherichia coli K-12 outer membrane protein $(\mathrm{OmpA})$ can inhibit synthesis of unrelated outer membrane proteins. J Mol Biol 216, 39-47.

Sidorczyk, Z., Zähringer, U. \& Rietschel, E. T. (1983). Chemical structure of the lipid A component of the lipopolysaccharide from a Proteus mirabilis Re-mutant. Eur J Biochem 137, 15-22.

Stoorvogel, J., van Bussel, M. J. A. W. M. \& van de Klundert, J. A. M. (1991). Biological characterization of an Enterobacter cloacae outer membrane protein (OmpX). J Bacteriol 173, 161-167. 
Storm, D. R., Rosenthal, K. S. \& Swanson, P. E. (1977). Polymyxin and related peptide antibiotics. Annu Rev Biochem 46, 723-763.

Tommassen, J., van Tol, H. \& Lugtenberg, B. (1983). The ultimate localization of an outer membrane protein of Escherichia coli K12 is not determined by the signal sequence. EMBO $J 2$, $1275-1279$.

Tsai, C.-M. \& Frasch, C. E. (1982). A sensitive silver stain for detecting lipopolysaccharides in polyacrylamide gels. Anal Biochem 119, 115-119.

Vaara, M. \& Viljanen, P. (1985). Binding of polymyxin B nonapeptide to gram-negative bacteria. Antimicrob Agents Chemother 27, 548-554.

VanBogelen, R. A. \& Neidhardt, F. C. (1990). Ribosomes as sensors of heat and cold shock in Escherichia coli. Proc Natl Acad Sci USA 87, 5589-5593.

VanBogelen, R. A., Hutton, M. E. \& Neidhardt, F. C. (1990). Geneprotein database of Escherichia coli K-12, 3rd edn. Electrophoresis 11, 1131-1166.

Webster, R. E. (1991). The tol gene products and the import of macromolecules into Escherichia coli. Mol Microbiol 5, 1005-1011.
Weiss, J., Franson, R. C., Schmeidler, K. \& Elsbach, P. (1976). Reversible envelope effects during and after killing of Escherichia coli by a highly purified rabbit polymorphonuclear leukocyte fraction. Biochim Biophys Acta 436, 154-169.

Weiss, J. S., Beckerdite-Quagliata, S. \& Elsbach, P. (1980). Resistance of gram negative bacteria to purified bactericidal leukocyte proteins. Relation to binding and bacterial lipopolysaccharide structure. J Clin Investig 65, 619-628.

Williams, M. D., Ouyang, T. X. \& Flickinger, M. C. (1994). Starvation-induced expression of SspA and SspB: the effects of a null mutation in sspA on Escherichia coli protein synthesis and survival during growth and prolonged starvation. Mol Microbiol 11, 1029-1043.

Yanisch-Perron, C., Vieira, J. \& Messing, J. (1985). Improved M13 phage cloning vectors and host strains: nucleotide sequences of the M13mp18 and pUC19 vectors. Gene 33, 103-119.

Yim, H. H. \& Villarejo, M. (1992). osm Y, a new hyperosmotically inducible gene, encodes a periplasmic protein in Escherichia coli. J Bacteriol 174, 3637-3644.

Received 4 February 1998; revised 23 March 1998; accepted 6 April 1998. 